Economic and social yield of investing in hiking tourism. The case of Berguedà, Spain.

Published in Journal of Travel and Tourism Marketing, 35:2, 148-161, 2018.

DOI: $10.1080 / 10548408.2017 .1350252$

Josep Raya ${ }^{1,}$, Esther Martinez-Garcia ${ }^{2}$, Dolors Celma ${ }^{3}$

1. Josep Raya. Department of Economics, School of Business, Tecnocampus-University Pompeu Fabra, Av. Ernest Lluch, 32; 08302 Mataró Mataró (Barcelona), Spain, josep.raya@upf.edu

2. Esther Martínez-Garcia, Department of Economics, Faculty of Tourism, University of Girona, Plaça Ferrater Mora, 1; 17004 Girona, Spain, esther.martinez@udg.edu, ORCID: 0000-0001-6828-4933

3. Dolors Celma, Department of Management and Business, School of Business, Tecnocampus-University Pompeu Fabra, Av. Ernest Lluch, 32; 08302 Mataró Mataró (Barcelona), Spain, mdcelma@tecnocampus.cat 


\title{
Economic and social yield of investing in hiking tourism. The case of Berguedà, Spain.
}

\begin{abstract}
Nature-based tourism is on the rise around the world. This article employs a cost-benefit analysis methodology to contribute to knowledge in this area by estimating both the economic impacts and the social costs and benefits of investing in hiking tourism. It includes tangible and non-tangible impacts, such as health benefits and $\mathrm{CO} 2$ emissions. Using data collected between $15^{\text {th }}$ March 2014 and $14^{\text {th }}$ March 2015, results show a positive return from every euro invested in hiking tourism. A single figure of net returns to society enables policy-makers to assess the social value of the investment itself and can help citizens' rational choice regarding whether to encourage or resist additional tourism development.
\end{abstract}

Keywords: sustainable development; hiking tourism; nature-based tourism; social yield, cost benefit analysis, economic impact; rural tourism

\section{Introduction}

Nature-based tourism is on the rise around the world. In many cases, rural regions see it as a relatively easy and low-polluting way to increase the economic wellbeing of their inhabitants by generating income, employment and tax revenue (Bonduelle, 2006; Hunt, Durham, Driscoll and Honey, 2015; Spanish Ministry of Agriculture, 2014; Moore and Ross, 1998). The higher the spending of tourists attracted by nature-based products and experiences (often referred to as "a high-yield niche market"), the more nature-based tourism is expected to boost the host economy 
(Dwyer and Forsyth, 2008). Nature-based tourism is attractive to rural areas, as it allows economic value to be generated from what in many cases are under-used and non-economically profitable natural resources. It can also be seen as way of generating resources to finance the maintenance and improvement of natural spaces (Mangan, Brouwer, Das Lohano and Nangraj, 2013; Mayer, 2014).

While tourism may generate economic benefits for the host community, it is also associated with costs (and benefits) that go beyond the economic to the social and environmental. A broad analysis has to include all of these costs and benefits, in line with what Dwyer and Forsyth (2008) call sustainable yield. A better knowledge of the characteristics and impact of this type of tourism provides for better destination management (Midmore, 2000), can aid cooperation between private businesses and the public sector to invest in this type of tourism, and can help citizens' rational choice regarding whether to encourage or resist additional tourism development (Fretchling, 2006). Within the framework of Cost Benefit Analysis (CBA), social, economic and environmental costs and benefits are generally referred to as "social" costs and benefits (Florio et al., 2014). It uses the same measurement unit (money) to value them, thus providing a single figure that enables managers to assess the aggregate social value of an investment or action in itself (investing in hiking trails in our case); it also allows for comparison with other activities and investments and is therefore a tool for deciding which provide higher social outputs for the society where they are implemented. It goes beyond the economic impact most local governments are initially interested in and places a monetary value on well-known social benefits (such as preserving nature and promoting healthy habits). This, in turn, provides knowledge regarding how important these benefits are for the society concerned. 
In recent years, the use of trails, greenways, and nature-based paths in general for leisure and tourism purposes has experienced notable growth in many countries, including Spain (Spanish Ministry of Agriculture, 2014; Mundet and Coenders, 2010). Hiking on nature-based paths has become very attractive and a relatively cheap way for rural areas to attract visitors. Apart from its benefits from the point of view of sustainable tourism, among modes of sports tourism, hiking is one with a high number of practitioners (Observatorio Europeo Leader, 2001). Investing in natured-based tourism may have many benefits for the local community and for hikers themselves. For the local community, it is a way of attracting visitors and therefore a potential boost for the local economy by generating economic revenue and employment (Moore and Ross, 1998; Turco, Gallagher and Lee, 1998). For hikers, walking for pleasure on nature-based trails can be an inexpensive way not only of enjoying oneself and socializing (Moore and Ross, 1998), but also of doing regular physical activity. By helping improve health (Hartig, 2006; Kaczynski and Henderson, 2007) it can also reduce healthcare costs for both individuals and the public sector (Zheng, Ehrlich and Amin, 2010). Other potentially relevant effects of natured-based tourism are helping to preserve nature and ecosystems, provided a proper balance is maintained with the negative effects of receiving visitors (More and Ross, 1998).

The aim of this article is twofold: first, to estimate the economic impact of investing in hiking paths (maintenance and signposting costs, promotion costs and the opportunity costs of land allocated for use as paths) at the nature-based location Berguedà in Catalonia (Spain). This article is also the first attempt in literature to calculate the social output (or an approximation of sustainable yield) of investing in hiking trails, through the implementation of a CBA. As noted by Bonduelle (2006), the 
Spanish Ministry of Agriculture (2014), and Mundet and Coenders (2010), although nature-based trails have great potential for tourism they have not received much attention in the sustainable tourism literature. Economic tourism literature has mainly only focused on the economic impacts of tourism activities, but these represent only a subset of (tourism) benefits (Mayer, 2014); CBAs have been performed for natural and protected areas and outdoor recreational spaces, but most trail and hiking cost-benefit analyses are unpublished or "grey" literature, or only constitute a partial analysis, and many of them are not applied to cases in Spain (Baylatry, Malivarn and Viravouth, 2015; Bowker, Bergstrom and Gill, 2007; Güell, 2014; Hartig, 2006; Mayer, 2014; Palau, Forgas, Blasco and Ferrer, 2012). The cost-benefit analysis conducted in this article includes most of the potentially relevant costs and benefits of hiking, or those it is possible to evaluate with the available information (such as health gains and the value of the pleasure of hiking). Therefore, we go further than many other studies that have been conducted on tourism impact, which have been exclusively interested in economic or environmental impacts (e.g. Spanish Ministry of Agriculture, 2014; Tudela and Giménez, 2009) but do not consider them all together, or indeed other potentially relevant social costs and benefits (Mayer, 2014). To our knowledge, this is also the first attempt in literature to measure both the economic benefits and social costs and benefits of an investment in hiking trails, doing a complete CBA. The analysis is conducted in Catalonia, Spain, the third world's top tourism destinations in number of tourists, and one which attempts to diversify its tourism from the traditional "sun and sand" product. Berguedà is an appropriate case of analysis since its economy has traditionally relied on mining and the textile industry and nowadays, after a dramatic decrease in these sectors, it is facing a transformation process in its economic 
model: the local authority is trying to direct this transformation towards tourism, and especially nature tourism.

The article is structured as follows. After a contextual section, section three includes the methodology, with general information about IO and SAM analysis, CBA, and the data compiled. It is followed by the results section, which also includes a brief discussion of the methods used in each case. Finally, the fifth section brings the article to a close with the conclusions. There are also two Appendixes. The first one covers some technical notes on the Input-Output Analysis; the second one is a robustness check on the results obtained, using an IO table for a different year than the one used in the article.

\section{Context of the analysis: Hiking and the region of analysis}

Hiking and walking along signposted trails is a physical activity that does not require much physical or technical training or specialized equipment, making it affordable for most people. If practiced in natural areas, it offers the possibility of learning about the countryside and rural areas, as well as enjoying nature. The extent of the spatial scale at which nature-based tourism operate is relevant for determining economic benefits as well as for management at institutional level (Weyland and Laterra, 2014). On the one hand, the benefit of nature-based tourism is not propagated as a tangible good to other areas. Thus, if we consider the visitor's residence place we can think of a non-material propagation of the nature-based tourism benefit in terms of memories or stress level reduction. As visitor's origin can be from nearby areas or as far as other continents, the benefit of a nature-based tourism experience can have an effect at very distant areas. On 
the other hand, the decision of the spatial scale implies a trade-off between extension and sampling effort. The nature-based tourism potential assessment demands a great effort in information collection about preferences that is usually gathered in situ or via telephone surveys (Eigenbrod et al., 2010). This restricts the possibility of making large scale evaluations. Once defined the scale of the assessment, it is important for each area to evaluate the real benefits and costs that nature-based tourism brings to it.

Defining the spatial scale is often a trade-off between extension and sampling effort. Due to the lack of previous data, a great effort in information collection is needed. This restricts the possibility of making large scale evaluations and, therefore, ACB are to be restricted, as in our case, on the benefits and costs for the host community.

The study presented here was conducted in Berguedà, a region situated in Barcelona Province in central Catalonia, north-east Spain, close to France. It is located halfway between the pre-Pyrenees and Pyrenees mountains and the Central Depression.

Berguedà has 41,744 inhabitants and its economy has traditionally relied on mining and the textile industry, aside from primary sector activities related to land. Nowadays, after a dramatic decrease in these sectors, it is facing a transformation process in its economic model. The local authority is trying to direct this transformation towards tourism, and especially nature tourism. For example, 2 Millions of euros were dedicated from 2015 to restore and create new paths close to Llobregat river to facilitate nature-based tourism. Berguedà has an area of 1,185.5 square kilometres, with a maximum altitude of 2,605 metres and a minimum of 400. In the northern part, known as Alt Berguedà (Upper Berguedà), there is a border of 2,000 peaks, which form part of the mountain range Cadí-Moixeró Natural Park. Furthermore, the region is divided by the Llobregat (river) valley. Hiking paths are structured through a network of 18 paths. The two most 
visited paths: "Cavalls del vent" (Wind horses) and "Camí dels bons homes" (Path of the good men). "Cavalls del vent" is a path of $82 \mathrm{~km}$ with 4800 meters of net increase in altitude. "Camí dels bons homes" is a path of almost $200 \mathrm{~km}$ with 5530 meters of net increase in altitude.

Spain has around 77,000 km of signposted paths, but a low density of signposted paths $(0.15 \mathrm{~km} / \mathrm{km} 2$; Spanish Ministry of Agriculture, 2014). Catalonia, in the north-east of Spain, has been one of the most active regions in Spain in signposting paths and has 3,500 Km of such paths. In Spain, path signposting in natural and rural areas was originally promoted by Catalan hikers at the beginning of the 20th century, and the first long distance path to be signposted in Spain was the 7-GR, located in Catalonia. Nowadays, trekking and hiking are quite popular among Catalans, and tourism and leisure facilities and products have been developed around paths. Catalonia is very attractive to hikers due to its varied natural landscape and mild climate.

\section{Methodology}

The analysis of the economic impact of hiking tourism in Berguedà includes the direct economic benefits and indirect and induced effects, which are computed using the Input-Output model (IO) with a Social Accounting Matrix (SAM) for the indirect and induced economic effects. A survey administered to hikers in Berguedà is used to calculate the direct economic impact. The social benefits and costs are included in the Cost Benefit Analysis subsection. 
Economic impact of hiking in Berguedà: direct impact and input-output and SAM analysis

This subsection is devoted to the analysis of the economic impact deriving from public investment in hiking tourism (signposting, maintenance, promotion....). Economic impact is generated by the money spent by visitors attracted to Berguedà to hike along its paths. A high percentage of studies only address the direct economic impact, which refers to hikers' spending in the area (on food, restaurants, hotels, shopping, etc.) such as the study by Kastenholz and Rodrigues (2007) on market segmentation according to hikers' expenditure. To measure indirect and induced effects, the most common methodology is the Input-Output (IO) Model, including the Social Accounting Matrix (SAM). IO models take into account interindustry input-output relations and final demand (i.e. consumption, investment, exports and imports) simultaneously (Pyatt and Round, 1979). Hence, the impact of an external demand shock on the economy (tourists' expenses - day-visitors and those who spent the night at destination) can be estimated. The tourism industry is composed of various sub-industries/sectors and hence any demand and/or supply-side shock given to the industry involves both industrial and inter-industry impacts. Actual tourist spending, usually determined through surveys, is the main input used to calculate economic impact throughout the IO analysis. A usual result is the multiplier effect that the spending of one category has on the host economy. The multiplier effect is the increase in final income due to knock-on effects within the local economy from new extra spending in this category. It is composed of the direct, indirect and induced multipliers. Direct effects are the increase in sales revenues of firms or tourist spending. Firms in turn purchase inputs from other firms in the region, which in turn purchase inputs from other firms, and so on. These are the indirect effects 
and are generally distributed among many economic sectors, as opposed to only those most directly associated with tourism, which is the case with direct effects from tourist spending. Finally, induced effects are generated when the receipts (increased incomes, such as employees' wages) of direct and indirect spending are spent. This generates further consumption, input spending by firms, and so forth, ultimately generating an increase in output, added value and employment in the host economy. Thus, the final increase in income in the host economy is generally higher than the initial increase generated by tourist spending. SAM models that include IO models are common in obtaining income multipliers for induced effects. As mentioned above, in terms of the spatial dimension of these effects we have restricted the area to the Berguedà.

Although the limitations of the traditional IO economic impact model are well known (Blake, Durbarry, Sinclair and Sugiyarto, 2001; Dwyer, Forsyth and Spurr, 2004; Sun, 2007), it is still commonly used in tourism and recreation studies (Klijs, Peerlings and Heijman, 2015). Criticisms of traditional IO models include the fact that relative prices are fixed, and therefore input substitution is not possible, factor inputs are infinitely available, and there is a linear relationship between direct and indirect effects. All these restrictions imply, amongst other things, that a positive increased (tourist) demand in a region will always generate an expansion of its economic activity and positive multiplier effects. Hence, economic impacts may be overestimated. General Equilibrium models (GEM) have been proposed as better models for evaluating economic impact (Blake et al, 2001; Dwyer et al, 2004), as have modified IO models, such as non-linear IO models (Klijs et al., 2015). Nevertheless, GEM require a large amount of information which, as in our case, is not always available. Moreover, as GEM and non-traditional IO analysts remark, when the region under analysis is not 
particularly large compared to the reference economy (Dwyer et al., 2004), or tourists' spending is not large enough to generate relative price changes (Klijs et al., 2015), traditional IO models are appropriate and provide realistic results. These two conditions are fulfilled in our case: Berguedà is a relatively small economic region in Spain (Bergueda's GDP is only around $0.05 \%$ of Spanish GDP), and hiking visitors' spending in Berguedà does not currently represent a very large change in final demand. We have therefore employed a traditional IO model to analyse the economic impact (direct plus indirect effects) of investing in hiking trails in Berguedà and a SAM for calculating induced effects.

The total multiplier from previous studies on hiking generally ranges between 1.5 and 1.8 (Midmore, 2000; Woodfin, 2010). We expect the multiplier to be within that range for Berguedà.

\section{Questionnaire data}

In order to estimate the direct economic impact, a survey was administered to hikers in the area several days each month over a year, from 15th March 2014 to 14th March 2015. Interview locations were strategic points of Pedraforca, Queralbs, Forn Freda and the Empedrats for which every hiker pass. As counting hikers was also an aim for the study, the interviewers were there from early hours in the morning in order to avoid double counting this day. Future double counting was avoided by asking the visitors for the last four numbers of its identification number. Days were selected prior to know the weather conditions. A probability sample stratified by season, day of the week and type of route was generated. The main reason for doing this was the need for the sample to be representative of all hiking visitors but also both seasons (high and off-season), time of the week (weekend or not) and type of route. This is due to the fact that direct 
economic impact depends on hiking visitors' expenditure profile, and this in turn can vary depending on the aforementioned variables (for instance, hikers visiting in the high season or at weekends tend to stay longer and therefore spend more). All interviewed hikers were selected randomly from all the hikers in the zone; 695 valid responses were collected (392 in peak-season ad 303 in off-season); non-response (only 21 of the responses) was treated as missing. Approximately $75 \%$ of the responses were from the weekend and $25 \%$ in work days. Along the years we administered the survey 60 week days and 36 weekend days. Since the number of hikers during a year is approximately 111,600 (82,752 in peak-season and 28,848 in off-season), using a $95 \%$ of confidence, the margin of error is $3.35 \%$. Obviously, this margin of error is slightly higher (but still under the usual threshold of 5\%), when we split the sample into two groups: off-season and peak season. In particular, the error margin is of $4.5 \%$ in peak season and $4.8 \%$ in off-season ${ }^{1}$.

The questionnaire included questions regarding expenses and their composition (accommodation, shopping, transport, etc.), but also other relevant information for estimating economic impact, such as whether they were locals or visitors, and in the latter case if hiking was the main purpose of their visit ${ }^{2}$. Hence, the survey gathered economic but also other information. Accordingly, the interview with hikers was divided into 6 different parts: socio-economic personal information, hiking habits,

\footnotetext{
${ }^{1}$ Population figures were provided by the local authority and come from counters. In this sense, our survey represent $0.6 \%$ of total hikers.

${ }^{2}$ Economic impact was generated using only the expenses of visitors (non-residents) whose main purpose of visit was to hike on signalled paths. They comprised $69.95 \%$ of all hikers surveyed.
} 
spending and contingent valuation through costless choice (a question used later in the CBA in order to obtain the "recreational value of walking").

\section{Cost Benefit Analysis}

Cost Benefit Analysis (CBA) considers economic benefits and other benefits of investing in nature-based trails for hiking, as well as economic and non-economic costs. It is therefore a methodology that goes one step further and evaluates some social variables and effects that other methodologies such as Input-Output Outcomes do not.

The costs and benefits included in a CBA are social in nature, i.e. social costs and social benefits, and include monetary and non-monetary as well as tangible and intangible costs and benefits. CBA measures all benefits and costs in monetary terms, so that a single measure of "social profitability", the "net benefit" (net present social value), can be obtained. If this figure is positive, net benefits are positive, i.e. social benefits exceed costs, and hence the investment is socially profitable. This way of proceeding also allows the comparison of alternative uses of resources or funds, and therefore allows the decision-maker to make investment decisions by comparing the net social value of alternative investments. CBA is usually used in public sector investment decisions; in fact, in many cases public projects have to pass a CBA before being implemented, to show and quantify their net social value.

In order to obtain a single figure of net social value, CBA needs to value all costs and benefits in (present time equivalent) monetary terms, including those which do not have a market price (intangibles; Florio, 2014). Calculating benefits from visitors' spending and economic impacts in the previous section was easier: staying in paid accommodation, food and beverages, sports equipment, for example, all have 
market prices. These market prices capture, under some assumptions (such as perfectly competitive markets), the valuation individuals place on goods or services as a measure of their willingness to pay for them. With intangibles, there is no market price and hence there is no observable monetary figure for individuals' valuations. In order to value intangibles different methodologies can be used. The basic methods are revealed preferences methods (indirect methods) and stated preference methods, such as contingent valuation methods (direct methods). Revealed preferences methods are based on an individual's market decisions (individuals paying or accepting compensation by buying or selling, for example), which can be used to "reveal" how individuals value the intangible. Some of the most commonly used methods, also used in this research, are the travel cost method, hedonic prices, human capital models and productivity models. Each case of analysis requires a specific method (for example, the travel cost method can be suitable for valuing natural parks with no entry price, but it may not be suitable when these are very near to individuals' homes). In contrast, stated preference methods are designed to find valuations in non-real cases, by asking individuals, with appropriate methods, about their willingness to pay or accept compensation in hypothetical market-simulated situations. Below, we present a first approach to a CBA of public investment in nature-based hiking trails.

\section{Results}

\section{Direct economic impact}

The following profiles of hikers were obtained from the survey (Table 1). The average age was around 40 (specifically, 39.78); men and women went hiking in almost equal 
numbers; 52.24\% had a university education, most hikers were employed (75.43\%) and had a permanent contract (71.07\%); 8 out of 10 worked in qualified professions and 7 out of 10 worked in the service sector. With respect to hikers' habits, they practiced this activity regularly (3.3 out of 10 hikers practiced it every week); $75 \%$ had hiked more than once in Berguedà but were considered sporadic hikers in the region. The main motivation behind the visit was hiking for most respondents $(65.79 \%)$. The most frequent number of people participating in the activity was two adults with no children under 15 years. The majority (52.46\%) were day trippers; and for those who stayed overnight, the average time spent in the region was 3.51 days and the average time devoted to hike 4 hours/day.

[Please insert Table 1 around here]

The highest and lowest $1 \%$ of per-person per-day expenditure were removed from the analyses. The average amount spent on accommodation per person and day was $€ 28.21^{3}$. Total hospitality estimated expenses (which basically means all accommodation expenses) were $€ 2,581,580.17$; total spending on shopping, other goods and services was $€ 2,524,115.03$ (most of this expenditure was on food and beverages $€ 24.45$ per person and $€ 1,617,416.71$ in total - but it also includes expenditure on sports, culture and other goods and services).

Finally, the total spending or direct economic impact of hiking tourists (day trippers and those spending the night in the area) in Berguedà amounted to $€ 5,105,695.20$.

\footnotetext{
${ }^{3}$ This figure has been calculated removing those people who were accommodated at second homes or in a home of family or friends.
} 


\section{IO analysis}

For the IO analysis, and hence to estimate indirect economic impact from visitors' expenses, an IO table of the region's economy and relationship between economic sectors is needed. We used the latest Catalan regional IO table available at the time of analysis, generated by the Catalan statistical office, Idescat, for 2005). This IO table was adapted to the 2014 sectorial structure of Berguedà. An aggregated expenditure for the 'hiking industry' was needed ${ }^{4}$. This figure was obtained from the information given in the survey by multiplying daily expenses by number of hikers (either the total of hiking visitors or only the proportion staying in paid accommodation, depending on the type of spending). Thus, two broad types of expenses were explicitly inserted into the Catalan IO table: shopping (which includes food and beverages, among others - €2,524,115) and hospitality $(€ 2,581,580)$. Indirect effects of the hiking industry were calculated using the well-known IO table multipliers (Tables 2 and 3). Direct plus indirect effects were $€ 7,425,915.8$ in terms of output; $€ 4,069,100.29$ in terms of added value and 83 in terms of employment. Hence, hiking tourism generates new production in the amount of $€ 7,425,915.8$, new added value totals $€ 4,069,100.29$ and 83 new jobs are generated (Table 2). Table 3 offers the direct and indirect impact of hiking, in terms of output, for each component of expenditure.

[Please insert Table 2 and Table 3 around here]

\section{The Social Accounting Matrix and induced effects}

\footnotetext{
${ }^{4}$ Tourism services are not regarded as a separate productive activity in national and regional IO tables; rather, they are included in specific sectors and expenditures such as hotel services or shopping expenses.
} 
The standard IO model is useful for estimating the indirect economic impact generated by visitors' expenditure, as it includes interdependence among production industries in an economy and provides information regarding intermediate and final demand. However, it is not enough to calculate induced effects. Induced effects are created when the new income generated in the region from visitors' spending is spent by employees and anyone whose income increases in general. This produces an additional effect on final demand. In order to calculate induced effects, macroeconomic accounts are needed. The link between the tourism (hiking) industry and the macroeconomy is obtained by inserting the Catalan IO table into a Social Accounting Matrix (SAM). A SAM presents a snapshot of the economy for a given year. It is a double-entry table that synthesizes and describes the structure of an economy in terms of the links between production, income distribution and demand. The revenue and expenditure of all agents and institutions in an economy are included (Thorbecke; 1998). As a square matrix that records flows of all transactions (by equalizing total expenditures/leakages to total incomes/injections), it provides a balanced macroeconomic position. The SAM includes an IO table and therefore one of its main limitations is that it is demand-driven and has an excess capacity assumption (Akkemik, 2012). However, this limitation is not very relevant in our case, as argued above.

To calculate induced economic effects, we have used the SAM built by Llop (2012) for the year 2005. It covers consumption-income relations in the Catalan economy. As can be seen in Table 4, including induced effects in the computations increases the previous economic impact figures, which only included direct and indirect effects. As showed in Table 4, total impact is $€ 8,313,870.09$ in terms of output; $€ 4,541,893.25$ in terms of added value and 93.10 in terms of employment (see appendix 1 for details on Input- 
output analysis). These figures, which have been territorialized in order to consider only Berguedà's economy, are significant in relative terms. The Value Added impact represents $0.55 \%$ of Berguedà's GDP ${ }^{5}$, while the employment impact represents almost $4 \%$ of total unemployment and compensates around $10 \%$ of the new unemployment originated by the loss of jobs in production industries. The output impact represents more than $1 \%$ of the GDP while the employment impact represents almost $4 \%$ Finally, the total multiplier generated by hiking visitors is 1.63 , in line with those previously found in the literature, which range from 1.5 to 1.8 (Midmore, 2000; Wilson, 2008).

[Please insert Table 4 around here]

Finally, some robustness checks were done. As Crompton (2006) and Jeong et al. (2016) note, some mischievous practices in economic impact analyses can be found with the aim of legitimizing a political position. We have avoided mischievous procedures in this analysis as follows. The first group of mischievous procedures are related to calculating the population of analysis. In this analysis, local residents were explicitly excluded from the calculations. In fact, the survey was only administered to visitors. Moreover, the number of visitors considered was calculated using a conservative approach. An initial estimation of numbers of hikers was provided by the local government in Berguedà. However, in order to validate these numbers, interviewers counted hikers during the survey. Using information for the distribution of hikers on the days of the survey, a global amount of visitors was calculated ${ }^{6}$, which was

\footnotetext{
${ }^{5}$ Bergueda's GDP in 2015 was 821.14 $€$ Millions and its Gross Added Value 757.0€ Millions (source: Catalan Statistical Office, macromagnitudes, 2015).

${ }^{6}$ Using the information we collected during the survey days we have constructed several normal distribution curves depending on the day of the week, the season and the type of route.
} 
$25 \%$ below the government figure. This last estimation was the one used in the calculus. With respect to replacement costs, since Berguedà is not a crowded destination, it is considered that visitors present at any time were not replacing other visitors ${ }^{7}$. Finally, casual visitors (for which the main motivation is not hiking) were excluded from the calculation by using a measure of primary trip purpose obtained from a question in the survey.

A second group of mischievous procedures relates to technical issues. Our sampling definition avoids these problems. Besides, the average per-person expenditure was calculated using individual weightings. Finally, the highest $1 \%$ and lowest $1 \%$ of perperson per-day expenditures were removed from the analyses, and non-response was treated as missing.

The third group of mischievous procedures are related to considering only economic impacts, and hence economic benefits, but forgetting the increase in monetary and nonmonetary costs than can also be generated. A cost benefit analysis allows the inclusion of these as well as other social costs and benefits. The next section presents a costbenefit analysis of public investment in hiking trails in Berguedà. This analysis includes both costs borne by the local community and opportunity costs (benefits if resources were redirected to other activities). Non-monetary benefits that cannot be included in an economic impact analysis are also included. In particular, this research includes health benefits from hiking and the value of the pleasure of walking, which can be assimilated as consumer surplus, since walking activity usually has no market price.

\footnotetext{
${ }^{7}$ Hikers during the weekend of "the Patum" event were excluded. This is the only time of year with possible displacement costs.
} 


\section{Net social value: Cost Benefit Analysis of investing in hiking trails in Berguedà}

A first issue to consider when carrying out a CBA is establishing a time horizon. The time horizon is particularly relevant for investment projects where the costs and benefits streams are generated at a different time (commonly, costs first and then benefits). In the case of Berguedà, hiking tourism used as main resource paths. Due to fact that paths are a natural resource that is not "created", they already exist (hence no initial investment is needed in their creation), although they do need some maintenance and relatively minor investments periodically. Therefore, it can be considered that costs and benefits flows coincide in time. Accordingly, the analysis presented below corresponds to one year, 2014, and no net present value calculations are needed.

A further issue is which benefits and costs to consider in a CBA. In this article, they have been chosen according to the literature on hiking and trails (Observatorio Europeo Leader, 2001; Chhetri et al., 2004; Barton et al., 2009), and the possibilities of being estimated using available information. The benefits for the population of Berguedà are: health benefits, the intrinsic value of hiking, the value of having paths close to dwellings and economic benefits (which were already estimated in the previous section). As for costs, tangible costs are included here: trail maintenance and signposting, promotion costs (monetary costs), and the opportunity costs of land allocated for paths. Environmental costs have also been estimated $\left(\mathrm{CO}_{2}\right.$ emissions). In all cases the spatial dimension considered is the Berguedà area. The selection criteria for chosen benefits and costs are data availability and expected value of the figure. An example could help to illustrate. One ignored cost is the cost of forest fires caused by 
hikers. In this case not only it is difficult to know if was a hiker the causant of the fire forest but also forest fires are few and due to a forest fire occurred in 1994, $77 \%$ of the forest area is very young, so the cost is relatively reduced. That is, concepts that we have not taken into account are insignificant. Below we will discuss another example for the case of the value for individuals of having a path close to a dwelling.

\section{Benefits}

Concerning health benefits, trails provide an incentive for hiking and hence the risk of diseases such as coronary heart cardiovascular disease (CVD) and disease incidence are reduced (Zheng et al., 2010). Since there are no market prices, alternative methods, such as the avoided costs method, have been used to value investments in health promotion. In particular, Zheng et al. (2010) proposed a model to calculate the monetary savings generated by public programmes that promote hiking ${ }^{8}$. This proposal is followed here to calculate averted health costs. The first step is to quantify the extent to which walking decreases the risk of cardiovascular disease (CVD). To do this, and due to a lack of other specific data, we use the relative risk obtained in Zheng et al. (2010): 0.745 . The second step is to quantify the proportion of CVD cases that would have been avoided if the individual had practiced hiking. For this calculation, we need the percentage of the sedentary ${ }^{9}$ population in Catalonia $(20.3 \%)$, which was obtained from the Health Survey of Catalonia $2013^{10}$. The result $(6.49 \%)^{11}$ is close to $6 \%$, which

\footnotetext{
${ }^{8}$ In this approach, there is no evaluation of the lack of productivity when someone suffers from CVD. This lack of productivity appears as the opportunity cost of having CVD (Leal, et al. 2006).

${ }^{9}$ Less than 30 minutes of moderate physical activity every day.

${ }^{10}$ It is assumed that the same proportion applies to Bergueda's population.
} 
is the percentage the World Health Organization considers the percentage risk of death from CVD that could be avoided if people were not sedentary. In the final step, we apply this percentage to direct cost savings related to physical activity $(2,445,938,010.50 €)$ obtained from the Cardiovascular European Disease Statistics in 2012. This cost is the amount of health care costs (direct) and non-health costs (indirect or productivity loss). Then, we calculate the net benefit subtracting to this figure the cost (direct and indirect) of leg fractures. Adjusting this quantity for the population of Berguedà, the gross savings of investing in hiking are obtained $(857,134.37 €)$. This figure is the annual saving for the population who practise hiking in Berguedà. However, health benefits of an investment in paths only accrue to those hikers who are encouraged to hike because of the investment; that is, only new hikers. Therefore, an estimation of new hikers is needed. This figure is calculated from the percentage of first time hikers obtained in the survey (2.07). This is a conservative estimate ${ }^{12}$. The estimated final figure of health benefits (annual averted health costs) for Berguedà's inhabitants from public investment in nature hiking trails is therefore $17,742.68 €$.

Another non-economic benefit of investing in hiking trails that has to be considered is the intrinsic value of hiking (pleasure or recreational value; Farré, 2003). As this is intangible, no market prices exist and alternative information has to be found. Stated preference methods, such as the contingent valuation method, can provide this information. They consist in using different techniques to ask the individual how much

\footnotetext{
${ }_{11} \delta \mathrm{PAF}=\frac{0,203 \times(1,342-1)}{1+0,203 \times(1,342-1)}=0,0649=6,49 \%$ where $\delta \mathrm{PAF}$ is the Population Attributable Factor (Zheng, 2010); and 1.342=1/0,745

12 It is conservative because we can assume that some proportion of the usual hikers from Berguedà also walk on a path close to their home.
} 
he values a given good or service. In the case of activities done in the forest and generally those that affect public goods which are generally consumed free of charge, these methods have to solve the problem posed by "protest zeros or values", by which many individuals tend to put a zero price when asked, not because they do not value the activity or good or service, but because they consider it unethical to place a monetary value on it or because they consider it should be provided free of charge (Halstead, Luloff and Stevens, 1992). An alternative is Murphy and Wall (2006) proposal of the contingent valuation method, known as the costless choice method. This consists in comparing the value for individuals of the "free" good or service, or without a market price (e.g. a leisure activity), with other similar leisure activities (such as visiting a museum or doing some sport), which do have a market price. Individuals are asked to compare the value of the non-market activities and the market ones (greater, less or same value). In the case of Berguedà, an average value of the intrinsic value of hiking was obtained $(20.3 €)$ from responses to a question in the questionnaire administered to hikers. The total amount of the intrinsic value of hiking was $248,197.95 €$, which is the result of multiplying $20.3 €$ by the number of hikers who are residents in Berguedà $(12,226)$.

In order to evaluate the robustness of the previous results, the opportunity cost of time was also estimated using the travel cost method. This method is generally used in studies that estimate the recreational value of nature-based facilities and parks (Císcar, 1995, Farré, 2003, Güell, 2014). According to this method, if an activity has no market price (such as hiking), its value can be assessed from the value individuals place on the resources devoted to it, as they have opportunity costs. In our case, resources individuals devote to hiking is basically time spent hiking. The value of time is 
considered, following standard labour supply models, to depend on wage rates, and whether it is working time or leisure time. The value of leisure time is usually assessed as a fraction of individual's wage or working time (ranging between $30 \%$ and 50\%) (Casey, Vukina and Danielson, 1995). Assuming that the average monthly salary in Spain is $2,200 €(17.63 €$ per hour, assuming a usual month of 30 days and the average of labour days and weekly labour hours in Spain) and using the lowest band for the value of leisure time (30\%, as in Mangan et al., 2013), we obtain a value of $5.29 €$ per hour. Multiplying this by a hiking time average (3.5 hours, which is a typical walk including travel), the value of the walk would be $18.51 €$. This value is very similar to the one obtained previously and directly from the survey using the costless choice model (20.3€). Note that estimation of the value of time devoted to hiking is conservative. This is to keep estimates of non-economic benefits from hiking from being too high so as not to counteract the estimated values of costs and justify public sector investment in hiking trails in an artificial way. We consider the estimate to be conservative for at least two reasons. Firstly, leisure time has been valued using the lowest band (30\%). Secondly, the average wage of hikers we have considered is probably low, given the economic profile of the interviewed hikers (which is mediumhigh).

The last benefit analysed is the value for individuals of having a path close to a dwelling (Daams et al., 2016). The basic method for obtaining this valuation is through an increase in prices of nearby houses: if people appreciate having a path close to their dwelling, they will be willing to pay more for it. This is what the hedonic pricing method aims to do: obtain the implicit value of the characteristics of a product in a market price. For example, if individuals positively value the existence of multiple 
services and shops, they will be willing to pay a higher price for a house downtown than on the outskirts. Equally, if individuals value the fact of being close to a wellmaintained network of hiking paths, this value can be estimated through the prices of houses located near the paths (Garcia, Montolio and Raya, 2010; Nicholls and Crompton, 2005). Due to the fact that the valuation of dwellings depends on factors other than having a path nearby, it is necessary to apply econometric models to isolate the effect of closeness to the path on housing prices. We did not have the data required for this. However, in Berguedà most paths are not very close to urban areas and, at best, a very very small part of house prices can be attributed to outdoor facilities. Moreover, the evolution of house prices in 2014 was flat (1.1\% growth according to the Spanish National Bureau and 0.3 negative rate according to the Spanish Ministry of Public Works). For all these reasons, in this study it was assumed that the benefits of hiking paths in the form of house prices were negligible.

To sum up, the intangible benefits are obtained by adding the estimated value of health benefits $(17,742.68 €)$ and the assessed intrinsic value of hiking $(248,197.95 €)$. This gives an annual benefit of $265,940.63 €$ in intangible benefits. The direct economic impact previously estimated was 5,105,695.20€. Therefore, intangible benefits represent $5.20 \%$ of the direct economic impact. This information is provided in Table 5.

[Please insert Table 5 around here]

\section{Costs}


Concerning costs, four types were considered: the costs of maintenance and signposting paths, promotion costs, opportunity cost of the land used for hiking, and environmental costs ( $\mathrm{CO}_{2}$ emissions). Table 6 shows the estimated amounts for each of these. The costs of maintenance and signposting paths between 2003 and 2013 were financed with grants received from a higher tier of government. Applying the corresponding cumulative inflation, the final value of these investments is estimated at $88,611 €$ per year. In addition, Berguedà's local government employs two people for maintenance of the paths, which cost $60,000 €$ (annual salary) each. To this quantity we must add a proportional part of the wage costs of those in charge of promoting the territory, since they also promote hiking on the paths. Personnel costs on the whole (for maintenance and promotion) are $138,000 €$. The opportunity cost of the land used for hiking was also computed. Of Berguedà's 1,184 square kilometres, it is estimated that $3.377 \%$ is devoted to hiking paths. The price of rural land in the province of Barcelona (where Berguedà is located) is $2.15 € /$ square metre. This price multiplied by the number of square metres allocated to paths in the region gives an opportunity cost of $86,000,000 €$. However, this is not the figure to be considered, but the annual opportunity cost of land allocated to hiking paths. This was obtained by dividing this amount by 100 (100 years is the life expectancy of the land according to Spanish business tax); this gives an amount of $860,000 €$.

Finally, a non-tangible environmental cost was also considered based on $\mathrm{CO} 2$ emissions from energy consumption by the hospitality and accommodation sector that serves hiking visitors. Following Ragab and Meis (2016), secondary data information sources were used to calculate the total consumption of energy related to the hospitality and 
shopping industry; specifically, from the Annual Energy Consumption Report (IDAE, 2013). In 2013, energy consumption by the shopping and hospitality industry in Spain was 45,255,813.953 MWh. To obtain the quantities of $\mathrm{CO}_{2}$ emitted per $\mathrm{KW} / \mathrm{h}$ electricity consumed, conversion factors for $\mathrm{CO}_{2}$ reported by the Intergovernmental Panel on Climate Change were used. Then, the tonnes of $\mathrm{CO} 2$ emitted by the shopping and hospitality industry in Spain were multiplied by its price. This price $(7.68 €$ per tonne of $\mathrm{CO}_{2}$ ) was obtained from the traded mean value in 2015 from the European System of $\mathrm{CO}_{2}$ Trading (SENDECO2). Finally, this figure was adjusted by the proportion of GDP generated by hiking in Berguedà with respect to GDP generated by the total hospitality and accommodation industry in Spain (both measured in euros). Environmental costs estimated in this way totaled $5,020.38 €$.

The annual costs of investing in hiking tourism are the sum of maintenance and signalling paths, promotion costs, opportunity costs of land used for hiking and the $\mathrm{CO}_{2}$ environmental costs. They are 1,091,631.79€, as showed in Table 6.

[Please insert Table 6 around here]

To sum up the results obtained from the analysis, it can be seen that adding the direct economic benefits, benefits for health and the intrinsic value of hiking gives a total annual social benefit of 5,371,635.83 $€$. Since benefits outweigh total costs $(1,091,631.70 €)$, it can be concluded that the net social benefit from investing in hiking paths in Berguedà is positive and high, 4,280,004.04€. This is a benefit-cost ratio of 4.92 , that is, every euro invested in hiking generates $€ 4.92$ value for the population of Berguedà. This is high social profitability for the area and its residents. It is also notable that each euro invested (maintenance and signalling paths, promotion 
costs, opportunity costs of land used for hiking, 1,086,611€) generates at least 0.24 euro in non-monetary benefits (health benefits and the intrinsic value of hiking, $265,940.6 €)$. Table 7 offers a summary of benefits and costs.

\section{Conclusions}

Hiking has a high potential for attracting visitors to rural and nature-based destinations. It has been found that it also can have relevant economic and social impacts. However, it has not received much attention in the tourism literature, especially with regard to quantifying both the benefits and costs of investing in hiking and in such a way as to offer a single figure that can be used to assess and decide on this and competing investments. We do this in this article by means of CBA, including economic or monetary costs and benefits, but also intangible effects, such as health benefits and environmental pollution. Results show that investing in hiking trails generates high net social values; it is a socially favourable option for land use and a cheap way to generate high economic revenues. It is worth mentioning that these results were obtained despite being cautious with our calculations in order to not artificially generate too high benefits.

The region where the research was conducted, Berguedà, can be viewed as a typical case of a rural and nature-based location where the public authorities see tourism as an easy and low-polluting way of increasing economic welfare after a decline in traditional economic activities. Our results show that economic benefits are positive, and compensation in part the job loss from industry decline. The positive direct economic effect is partially due to the fact that hikers attracted by the network of hiking paths had a medium-high spending capacity. Multiplier effects were also important: the 
economic impact of the direct expenditure by hikers is multiplied by 1.63 considering indirect and induced effects on the economy. This multiplier is within the bands found in previous related studies (Midmore, 2000; Woodfin, 2010). As means of exportability of the economic benefits, in the Berguedà, unlike Barcelona (for example), the majority (more than 90\%) of the owners of the hospitality and accommodation industry are from the local area. In this sense, we can conclude that economic benefits remain in the area.

Another relevant issue is that investing in hiking tourism also generates non-economic benefits, which have also been quantified: health benefits to locals and the intrinsic value of hiking. However, attracting visitors does not come at zero cost. There are investment costs (signposting paths) and maintenance costs, as well as promotion costs and the opportunity costs of land allocated to paths. It is worth mentioning that opportunity costs were found to be high. This shows how important it is to consider all costs, and especially opportunity costs for all resources and not only direct cash costs. It is worth pointing out that this study has also considered environmental costs generated by visitors: $\mathrm{CO}_{2}$ emissions generated to serve visitors' needs (accommodation, food, etc.). Thus, this study has considered not only the most attractive part of the analysis for public agencies and governments - the economic benefits of attracting visitors to a destination - but also negative effects.

Our results show that in monetary terms, direct economic impact is the largest of all benefits and direct costs of investing in hiking tourism (annual investment plus wages) are relatively low. Hence, from this point of view, we can state that investing in hiking tourism is very profitable. Evidently, we need not only nice resources but also a suitable offer of hospitality services. However, it is also noticeable that considering intangible benefits alone (health benefits and the intrinsic value of hiking) also proves 
to be socially profitable, since the benefits exceed direct costs. Finally, the overall result obtained from the CBA, and therefore including all costs and benefits, not only economic ones, is very positive: every euro invested by the public sector in hiking tourism produces a return to society close to 5 euros. As with the analysis of the economic impact, the methods and hypothesis used to obtain this result with the CBA were also quite restrained, with the aim of avoiding generating too high a positive figure; what Crompton (2006) and Jeong et al. (2016) refer to as mischievous practices, that is, to avoid practices aimed at legitimizing a political position, in our case, in favour of investing in hiking tourism.

Other impacts apart from the ones already included here might be added in future research. For example, the existence of paths is a value in itself. Hiking is considered to be a sustainable tourism activity from the environmental point of view, which can help to maintain the landscape as a (tourist) resource for future generations. Investments in hiking tourism can also have a positive effect in terms of building a local civic network which identifies with its territory and enjoys its surroundings. An example of this is that in some places, local volunteers maintain paths. Investing in hiking tourism can also be a way for residents to have easy (sustainable and cheap) access to farms and common areas (Spanish Ministry of Agriculture 2014). Further research could explore these benefits, as well as costs not considered in this analysis (mainly other environmental costs). Further research can also be done in other hiking destinations, for which this research on Berguedà may prove helpful.

To sum up, the main contributions of a CBA in hiking paths, for practice and policy, revolves around the fact that it offers information for policy-makers that helps to take better informed decisions on investing on hiking and has the advantage of putting an 
accent on many effects, both benefits and also costs, that are generally not accounted for by local and regional governments and organizations; these see nature-based tourism as a source of boosting local economies and economic wellbeing for their residents, and focus nearly exclusively in the direct economic impacts of investing in nature based tourism in general and in hiking paths in particular.

It is also relevant for the academy, as it gives a more comprehensive view than partial studies that have been previously done. In this respect, it is important to mention that CBA includes economic, but also environmental and social effects, costs and benefits, and hence is taking a more comprehensive view than just focusing on one dimension of the effects (such as environmental impacts, generally negative, or economic benefits). However, performing CBA generally comes with methodological caveats, which in many instances are not under researcher's control. This is also in our case. Firstly, in many cases available IO tables include information which is not upgraded to the year of the analysis. This has also happened in our case. IO tables are generated by public agencies once only every five, seven or ten years. The economic conditions and the tourism industry may have changed since then. However, given the economic crisis suffered in Spain, tourism has increased rather than decreased its weight in the economy. The economic impact figures obtained here (indirect and induced effects) are therefore not expected to be overestimated. In fact, the robustness check included in Annex 2 shows this. Secondly, some hypotheses had to be made and indirect data had to be used in some cases. Finally, cost benefit analysis is grounded in neoclassical economic theory, and it uses money (or willingness to pay or accept compensation) as a measure of value, which is affected by the ability to pay. Moreover, it is based on ethical individualism (or welfarism), according to which social welfare is assessed on 
the basis of adding the individual utility of society's members; society's welfare is not different from its members' welfare. However, CBA allows equity issues to be included as well, and different groups in society may be weighted different in generating the aggregate social welfare. Hence, the methodology comes with its own characteristics and limitations. That said, it is rigorous, academically prestigious and used in the practice of evaluating new public investments. Therefore, tourism research can benefit from using this methodology for expanding knowledge on nature -based tourism, an area of research which is receiving increasing attention by academics; it can also be used for the analysis of sustainable tourism, as conceptually tries to include all relevant costs and benefits, not only economic ones, but also social and environmental. 


\section{Appendix 1: Some technical notes on the Input-Output Analysis}

From the identity: $\mathrm{X}=\mathrm{A} \mathrm{X}+\mathrm{D}$

where $X$ of total output, A input-output coefficient matrix, and D the demand vector.

We can obtain:

$$
X=(I-A)^{-1} D
$$

As a result, change in total output as a consequence of a change in demand:

$$
\Delta \mathrm{X}=(\mathrm{I}-\mathrm{A})^{-1} \Delta \mathrm{D}
$$

The Matriz $M s=(I-A)^{-1}$ es denomina is the matrix of simple multipliers (or the inverse Leontieff matrix) and measure interdependence impact (direct and indirect) of a demand change. The sum of the coefficients of every column permit us to obtain the output multipliers. Value-added and employment multipliers are obtained premultipliying the Leontieff matrix by the row vector VA/output (v) and employment /output, $(\ell)$ respectively.

The accounts of the SAM matrix are classified in m endogenous I $n$ exogenous. Where $X m$ and $X n$ are the output, income o spending indexes. Normalizing all the SAM flows:

$$
\left[\begin{array}{l}
X_{m} \\
X_{n}
\end{array}\right]=\left[\begin{array}{ll}
A_{m m} & A_{m n} \\
A_{k n} & A_{n n}
\end{array}\right]\left[\begin{array}{l}
X_{m} \\
X_{n}
\end{array}\right]
$$


Solving by the endogenous accounts:

$$
\begin{aligned}
& X_{m}=A_{m m} X_{m}+A_{m n} X_{k} \\
& X_{m}=\left(I-A_{m m}\right)^{-1} A_{m n} X_{n}=M_{a} Z
\end{aligned}
$$

where $M a=(I-A m m)^{-1}$ is the SAM multipliers matrix (or expanded multiplier matrix).

The difference between (Ma - Ms) is the induced impact.

We can also calculate value-added and employment impact. For example, the increase in employment needed $(\Delta E)$ to accommodate an increase in the demand $(\Delta D)$ is:

$$
\Delta E=\ell \Delta D+\ell\left(M_{s}-I\right) \Delta D+\ell\left(M_{a}-M_{s}\right) \Delta D
$$




\section{Appendix 2: Robustness check}

Since January 2016 (last revision was in September 2016) there is an update of the Input-Output table of Catalonia corresponding to the year 2011. The new IO Table has 82 branches rather than the 65 branches in the IO Table in 2005. During these years there have been changes in the productive structure of Catalonia. However, these changes are not so pronounced (Garcia and Bosch, 2015). In fact, the 8 main sectors in 2005 are also the main sectors in 2011. Small changes are observed in terms of the order of the main sectors and the lower weight of industrial sectors in 2011 , which may be a consequence of both the loss of industrial jobs in the recent crisis and as a result of different sectoral disaggregation in IO tables among of the two years. However, our calculations were made using 2005 Catalan IO Table adapted to the 2014 sectorial structure of Berguedà. Keeping this in mind, it is a reasonable assumption that if we use the 2011 Catalan IO Table also adapted to the 2014 sectorial structure of Berguedà, the results do not change significantly. Table A2.1 reports the same output as Table 4 but using the new IO Table. Results are similar, although slightly higher impacts are observed with the new IO Table, especially in the case of total employment impact (which is now almost $7 \%$ higher). Finally, the total multiplier generated by hiking visitors is now 1.71, also in line with those previously found in the literature (from 1.5 to 1.8 ) and slightly higher than the calculated with the IO Table of 2005. To sum up, using Catalan IO Table of 2005 we were being conservative.

[Insert Table A2.1 here] 


\section{References}

\section{References}

Akkemik, A.K. (2012). Assessing the importance of international tourism for the Turkish economy: A social accounting matrix analysis. Tourism Management, 33 (4), 790-801.

Barton J., Hine, R. \& Pretty, J. (2009). The health benefits of walking in greenspaces of high natural and heritage value. Journal of Integrative Environmental Sciences, 6, 261-278.

Baylatry, M., Malivarn, S., \& Viravouth, P. (2015). A cost-Benefit Analysis of ecotourism: a case study of Xe Pian National Protected area, Champsak Province, Lao PDR, in James, D., \& Francisco, H.A. (eds.) Cost-Benefit Studies of Natural Resource Management in Southeast Asia, Springer Science+Business Media, Singapore, 227-250.

Blake, A., Durbarry, K., Sinclair, M.T., \& Sugiyarto, G. (2001). Modelling tourism and travel using tourism satellite accounts and tourism policy for forecasting models, Tourism and Travel Research Institute Discussion Paper 2001/4.

Bounduelle, M. (2006, November, 24-25). Voies vertes en France: un joker durable pour le tourisme . Paper presented at the Technical Conference Greenways in Europe, Girona, Spain.

Bowker, J.M., Bergstrom, J.C. , \& Gill, J. (2007). Estimating the economic value and impacts of recreational trails: a case study of the Virginia Creeper Rail Trail. Tourism Economics, 13(2), 241-260.

Casey, J.F., Vukina, T., \& Danielson, L.E. (1995). The Economic value of hiking: further considerations of opportunity cost of time recreational demand models, Journal of Agricultural and Applied Economics, 27 (2), 658-668.

Chhetri, P., Arrowsmith, C. \& Jackson, M. (2004). Determining hiking experiences in nature-based tourist destinations. Tourism Management, 25, 31-43.

Císcar, J. (1995). Análisis coste-beneficio del Parque Nacional de Ordesa y Monte Perdido. Documento de Trabajo SGCIP-95, 4.

Crompton, J. L. (2006). Economic impact studies: instruments for political shenanigans? Journal of Travel Research, 45, 67-82.

Daams, M. N., Sijtsma, F. J. \& Van Der Vlist, A. J. (2016). The Effect of Natural Space on Nearby Property Prices: Accounting for Perceived Attractiveness. Land Economics, 92, 389-410.

Dwyer, L., \& Forsyth, P. (2008). Economic measures of tourism yield: what markets to target?, International Journal of Tourism Research, 10 (2), 155-168.

Dwyer, L., Forsyth, P., \& Spurr, R. (2004). Evaluating tourism's economic effects: new and old approaches, Tourism Management, 25 (3), 307-317.

Eigenbrod F., Armsworth P. R., Anderson B. J., Heineneyer A., Gillins S., Roy, D. B., Thomas, C. D. \& Gaston, K. J. (2010). The impact of proxy-based methods on mapping the distribution of ecosystem services. Journal of Applied Ecology, 47, $377-385$.

Farré, M. J. (2003). El valor de uso recreativo de los espacios naturales protegidos: una aplicación de los métodos de valoración contingente y del coste del viaje. Estudios de Economía Aplicada, 21, 297-320. 
Florio, M. (2014). Applied welfare economics: Cost-benefit analysis of projects and policies, Routledge.

Fretchling, D. (2006). An assessment of visitor expenditure methods and models. Journal of Travel Research, 45, 26-35.

Garcia, J. and J. Bosch (2015). Els Efectes d'Arrossegament i de soport de les branques

d'activitat de l'economia catalana. Una Anàlisi a partir de l'Marc Input-Output de

Catalunya. In Col-lecció Conèixer la Indústria II, Fundació per la Indústria, Sabadell.

Garcia, J., Montolio, D. \& Raya, J. M. (2010). Local Public Expenditures and Housing Prices. Urban Studies, 47, 1501-1512.

Güell, J. C. (2014). El ánalisis coste-beneficio y sus aplicaciones a proyectos relacionados con el turismo y la recreación. Papers de Turisme, 53-62.

Halstead, J. M., Luloff, A. \& Stevens, T. H. (1992). Protest bidders in contingent valuation. Northeastern Journal of Agricultural and Resource Economics, 21, 160-169.

Hartig, T. (2006, November, 24-26). Using greenways to amplify the health benefits of physical activity, Paper presented at the Technical Conference Greenways in Europe, Girona, Spain.

Holden, A. (2003). Investigating hikers' attitudes to the environment of Annapurna, Nepal. Tourism Management, 24, 341-344.

Hunt, C.A., Durham, W.H., Driscoll, L., \& Honey, M. (2015). Can ecotourism deliver real economic, social, and environmental benefits? A study of the Osa Peninsula, Costa Rica, Journal of Sustainable Tourism, 23 (3) 339-357.

IDAE, Instituto Para la Diversificación y el Ahorro de la Energía (2013): Informe Anual de Consumos energéticos.

Jeong J. Y., Crompton, J. L. \& Dudensing, R. M. (2016). The Potential Influence of Researchers" "Hidden" Procedure Decisions on Estimates of Visitor Spending and Economic Impact. Journal of Travel Research, 55 (7), 874-888.

Kaczynski, A. T. \& Henderson, K. A. (2007). Environmental Correlates of Physical Activity: A Review of Evidence about Parks and Recreation, Leisure Sciences, 29 (4), 315 - 354.

Kastenholz, E. \& Rodrigues A. (2007). Discussing the Potential Benefits of Hiking Tourism in Portugal, Anatolia, 18:1, 5-21.

Klijs, J., Peerlings, J. \& Heijman, W. (2015). Usefulness of non-linear input-output models for economic impact analysis in tourism and recreation. Tourism Economics, 21 (5), 931-956.

Leal, J., Luengo-Fernández, R., Gray, A., Petersen, S. \& Rayner, M. (2006). Economic burden of cardiovascular diseases in the enlarged European Union. European Heart Journal, 27, 1610-1619.

Llop, M. (2012). The role of saving and investment in a SAM price model. The Annals of Regional Science, 48, 339-357.

Mangan T., Brouwer, R., Das Lohano, H., Nangraj, G. M. (2013). Estimating rthe recreational value of Pakistan's largest freshwater lake to support sustainable tourism management using a travel cost model, Journal of Sustainable Tourism, 21, 3, 473-486. 
Mayer, M. (2014). Can nature-based tourism benefits compensate for the costs of national parks? A study of the Bavarian Forest National Park, Germany. Journal of Sustainable Tourism, 22 (4), 561-583.

Midmore, P. (2000). The economic value of walking in rural Wales. An independent report produced for the Ramblers' Association in Wales.

Moore R.L. \& Ross, D.T. (1998). Trails and receational greenways: corridors of benefits. Parks \& Recreation, 33 (1), 69-79.

Mundet, LL. \& Coenders, G. (2010). Greenways: a sustainable leisure experience concept for both communities and tourists, Journal of Sustainable Tourism, 18 (5), 657-674.

Murphy, W. \& Wall, S. (2006). Forest recreation in a commercial environment. Smallscale forestry and rural development: The intersection of ecosystems, economics and society, 347-356.

Nicholls, S. \& Crompton, J.L. (2005). The impacts of greenways on property values: evidence from Austin, Texas. Journal of Leisure Research, 37(3), 321-341.

Observatorio Europeo Leader (2001). La valoración del turismo de senderismo en los territorios rurales. Cuadernos de la Innovación, 12.

Palau, R., Forgas, S., Blasco, D. \& Ferrer, B. (2012). An Analysis of Greenways from an Economic Perspective, Tourism Planning \& Development, 9 (1), 15-24.

Pyatt, G. \& Round, J. I. (1979). Accounting and fixed price multipliers in a social accounting matrix framework. The Economic Journal, 850-873.

Ragab, A. M. \& Meis, S. (2016). Developing environmental performance measures for tourism using a Tourism Satellite Accounts approach: a pilot study of the accommodation industry in Egypt. Journal of Sustainable Tourism, 1-17.

Spanish Ministry of Agriculture (2014). Impacto económico y social del Programa de Caminos Naturales. Spanish Ministry of Agriculture, Madrid.

Sun, Y.Y. (2007). Adjusting input-output models for capacity utilization in service industries, Tourism Management, 28 (6), 1507-1517.

Thorbecke, E. (1998). Social Accounting Matrices and Social Accounting Analysis, in: W. Isard et al. (Eds.), Methods of International and Regional Analysis, Ashgate Publishing Company, Brookfield, VT.

Tudela, M.L., \& A.I. Giménez (2009). Valoración de impactos y propuestas de actuación del senderismo como actividad turística en el noroeste de la región de Murcia. Papeles de Geografía, 49-50, 147-158.

Turco D., Gallagher, L. \& Lee, K. (1998). Resident attitudes toward rail-trail development. Parks and Recreation, 33(4), 49-52.

Weyland, F. \& Laterra, P. (2014). Recreation potential assessment at large spatial scales: A method based in the ecosystem services approach and landscape metrics. Ecological Indicators, 39, 34-43.

Wilson, T. D. (2008). Economic and Social Impacts of Tourism in Mexico. Latin American Perspectives, 35, 37-52.

Woodfin, B. (2010). Maximising the benefits of walking tourism. Economic impact of walking tourism in West Cork. West Cork Development Partnership.

Zheng, G, H., Ehrlich, F. \& Amin, J. (2010). Economic evaluation of the direct healthcare cost savings resulting from the use of walking interventions to prevent coronary heart disease in Australia. International Journal of Health Care Finance and Economics, 10, 187-201. 
Table 1. Summarized results from the survey. Hiker profile (\%), hiking habits and other $\underline{\text { relevant information }}$

Age

39.78

Men

56.12

University graduates

52.24

Employed

75.43

Have a permanent contract

71.07

Qualified profession

82.16

Work in the service sector

71.54

Hike every week

Has previously hiked in Berguedà

$75 \%$

Hiking as main motivation

$65.79 \%$

Day trippers

$52.46 \%$

Length of the stay (for tourists-no day trippers)

3.51 nights 
Table 2 Direct plus indirect impact of hiking

\begin{tabular}{lc}
\hline & Direct+Indirect \\
\hline Output & $€ 7,425,915.8$ \\
Value Added & $€ 4,069,100.29$ \\
Employment & 83 \\
\hline
\end{tabular}

$\underline{\text { Table 3. Direct and indirect impact of hiking. Output }}$

\begin{tabular}{lrrr}
\hline & Direct & Indirect & Direct+ Indirect \\
\hline Hospitality & $€ 2,581,580.17$ & $€ 11,364.77$ & $€ 2,592,945.48$ \\
Shopping & $€ 2,524,115.03$ & $€ 315,341.43$ & $€ 2,839,456.45$ \\
Other & -- & $€ 1,993,513.87$ & $€ 1,993,513.87$ \\
Total & $€ 5,105,695.20$ & $€ 2,320,220.07$ & $€ 7,425,915.80$ \\
& & & \\
\hline
\end{tabular}


Table 4. Total impact of hiking.

Concept

Total $=$ Direct + indirect + induced

Output

$€ 8,313,870.00$

Value Added

$€ 4,541,893.25$

Employment

93.10

$\underline{\text { Table 5. Benefits from hiking investment }}$

\begin{tabular}{ll}
\hline Concept & Benefit
\end{tabular}

Intangible benefits

$€ 265,940.63$

Health benefits

$€ 17,742.68$

Hiking intrinsic value

$€ 248,197.95$

Direct Economic impact

$€ 5,105,695.20$

Total (intangible+direct)

$€ 5,371,635.83$ 
Table 6. Costs of investing in hiking paths

\begin{tabular}{ll}
\hline Concept & Cost \\
\hline Annual & $€ 88,611.41$ \\
investment & \\
& $€ 138,000$ \\
Wages & \\
Opportunity cost & $€ 860,000$ \\
of land & \\
& \\
Environmental & $€ 5,020.38$ \\
costs & \\
\hline
\end{tabular}


Table 7. Summary of benefits and costs $(€)$

\section{B. Benefits}

B.1 Intangible benefits

Health

$17,742.68$

Hiking intrinsic value

$248,197.95$

B.2 Direct Economic impacts

$5,105,695.20$

B.3 Direct+indirect+induced economic benefits (Value

$4,541,893.25$ added)

B.4 Subtotal (intangible benefits+ direct economic impact)

$5,371,635.83$

\section{Costs}

C.1 Annual investment +wages

$1,086,611$

C.2 Opportunity cost of land

860,000

C.3 Environmental costs $\left(\mathrm{CO}_{2}\right)$

$5,020.38$

C.4 Total costs

$1,091,631.79$

Ratio (B/C) (B.4/C.4)

4.92

Net social benefit (B.4-C.4)

$4,280,004.04$ 
Table A2.1. Total impact of hiking using Catalan IO Table for 2011

\begin{tabular}{ll}
\hline Concept & Total $=$ Direct + indirect + induced
\end{tabular}

Output

$€ 8,763,650.37$

Value Added

$€ 4,817,799.27$

Employment

99.68 